Atıf İçin: Koç F, Şamlı HE, Coşkuntuna L, 2021. Farklı Yem İşleme Teknolojilerinin Arpanın (Hordeum vulgare L.) Kimyasal, Mikrobiyolojik ve Mikroskopik Özellikleri Üzerine Etkileri. Iğdır Üniversitesi Fen Bilimleri Enstitüsü Dergisi, 11(3): 2446-2455.

To Cite: Koç F, Şamlı HE, Coşkuntuna L, 2021. The Effects of Different Feed Processing Technology on Chemical Microbiological and Microscopic Features on Barley (Hordeum vulgare L.). Journal of the Institute of Science and Technology, 11(3): 2446-2455.

\title{
Farkı Yem İşleme Teknolojilerinin Arpanın (Hordeum vulgare L.) Kimyasal, Mikrobiyolojik ve Mikroskopik Özellikleri Üzerine Etkileri
}

\author{
Fisun KOÇ ${ }^{*}$, Hasan Ersin ŞAMLI ${ }^{1}$, Levend COŞKUNTUNA ${ }^{1}$
}

ÖZET: Araştırmanın materyalini, arpanın farklı işlenmiş formları (öğütülmüş, flake ve ezme) oluşturmuştur. Yem örnekleri $4{ }^{\circ} \mathrm{C}, 22{ }^{\circ} \mathrm{C}$ ve $32{ }^{\circ} \mathrm{C}$ sıcaklıkta 90 gün depolanmıştır. Araştırma süresince yem örneklerinde kimyasal, mikrobiyolojik ve mikroskopik analizler yürütülmüştür. Araştırma sonucunda yemlerin kuru madde (KM), ham protein (HP), ham yă̆ (HY), ham kül (HK), ham selüloz (HS) ve nişasta değeri üzerinde yemin depolama süresi, depolama sicaklığı ve yemin formunun istatistiki olarak önemli olduğu tespit edilmiştir $(\mathrm{P}<0.001)$. Yemlerin mikrobiyal kompozisyonu üzerinde yemin formu etkili olmuş, en az etkilenme flake formundaki yemlerde tespit edilmiştir. Çalışmada $4{ }^{\circ} \mathrm{C}$ de ve $22{ }^{\circ} \mathrm{C}$ depolanan yemlerin maya ve enterobakteri içerikleri süreye bağlı olarak artmıştır $(\mathrm{P}<0.001)$. Çalışma kapsamında mikroskopla yapılan ölçümlerde küflerin tespiti mümkün olmamıştır. Bu açıdan stereo mikroskobun özellikle depolama süresi uzun olan çalışmalarda kullanılabileceğini söyleyebiliriz.

Anahtar Kelimeler: Arpa, depolama süresi, sıcaklık, yem formu, yem mikroskopisi

\section{The Effects of Different Feed Processing Technology on Chemical, Microbiological and Microscopic Features on Barley (Hordeum vulgare L.)}

\begin{abstract}
Different forms of processed barley (ground, flake and crushed) formed the material of the study. Feed samples were stored at $4{ }^{\circ} \mathrm{C}, 22{ }^{\circ} \mathrm{C}$ and $32{ }^{\circ} \mathrm{C}$ for 90 days. During the research, chemical, microbiological and microscopic analyzes were carried out on feed samples. As a result of the research, it was determined that feed storage time, storage temperature and feed form were statistically significant on the dry matter (DM), crude protein $(\mathrm{CP})$, eter extract (EE), crude ash (CA), crude fiber (CF) and starch values of feeds $(\mathrm{P}<0.001)$. Feed form had an effect on the microbial composition of feeds and the least affected feed was detected in flake form. In the study, the yeast and entobacteria contents of feeds stored at $4{ }^{\circ} \mathrm{C}$ and $22{ }^{\circ} \mathrm{C}$ increased depending on the time $(\mathrm{P}$ $<0.001)$. Within the scope of the study, it was not possible to detect molds in the measurements made with a microscope. In this respect, we can say that the stereo microscope can be used especially in studies with long storage times.
\end{abstract}

Keywords: Barley, storage time, temperature, feed form, feed microscopy

${ }^{1}$ Fisun KOÇ (Orcid ID: 0000-0002-5978-9232), Hasan Ersin ŞAMLI (Orcid ID: 0000-0002-5462-8384), Levend COŞKUNTUNA (Orcid ID: 0000-0002-5978-9232), Tekirdağ Namık Kemal Üniversitesi, Ziraat Fakültesi, Zootekni Bölümü, Tekirdağ, Türkiye

*Sorumlu Yazar/Corresponding Author: Fisun KOÇ, e-mail: fkoc@nku.edu.tr 


\section{GİRIȘ}

Tahılların besin değerinin arttırılmasında yem işleme tekniklerinden sıkça faydalanılmaktadır. Bugüne değin, partikül boyutunu küçülten öğütme ile başlayan, sonrasında ezme ile devam eden yem işleme tekniklerinin yanı sıra, teknolojinin gelişmesi ile ısıl işlem, buhar ve basınç uygulamalarının da kullanıldığı farklı uygulamalar geliştirilmiştir. Tahılların işlenmesinin ana amacı metabolik enerjiden yararlanımın arttırılmasıdır. İşlemden geçirilmiş pek çok tahılın tüm dane ile kıyaslandığında metabolik enerjisinin daha yüksek olduğu belirtilmektedir (Zinn ve ark., 2002). Aynı zamanda, işleme tekniklerinin yemlerde bulunan protein, nişasta ve selülozun sindirim oranı, yeri ve dağılımını da etkilediği bildirilmektedir (Mathison, 1996). Yüksek kaliteli yem üretmek amaciyla, hammaddelerin ve üretilen karma yemlerin kalite kontrolü özellikle önem taşımaktadır. Hammaddelerin kalitesiz olması, olası bulaşmalar, anti besleme faktörü içeriği ya da toksik bileşenler yemlerin besin içeriklerinden yeterince yararlanılamamasına yol açmaktadır (Khajarern ve Khajarern, 2008). Hayvanlardan kaliteli ürün elde edilmesinde yemlerin içerdiği besin maddelerinin yanı sıra mikrobiyolojik özellikleri de büyük önem taşımaktadır (Basmacıoğlu ve Ergül, 2002). Aynı zamanda yemlerin fazla miktarda mikroorganizma taşıyıcısı olduğu bilinmektedir. Bu nedenle kaliteli bir yemin besin maddelerinin miktar ve kullana bilirliği bakımından üstün özelliklere sahip olması istenmektedir. Bu çalışmada, depolama süresi ve sıcaklıklarının farklı formda üretilen arpanın bazı özellikleri üzerindeki etkileri, yem mikrobiyolojisi ve yem mikroskopisi teknikleri kullanılarak incelenmiştir.

\section{MATERYAL VE METOT}

Araştırmanın materyalini arpanın farklı işlenmiş formları (öğütülmüş, flake ve ezme) oluşturmuştur. Yem örnekleri 3 farklı depolama sicaklığında $\left(4{ }^{\circ} \mathrm{C}\right.$ sicaklık, \%14 nem; $22{ }^{\circ} \mathrm{C}$ sicaklık, $\% 47.7$ nem; $32{ }^{\circ} \mathrm{C}$ sıcaklık, \%26 nem), 90 gün süre ile depolanmıştır.

\section{Kimyasal Analizler}

Araştırma yemlerinde kuru madde (KM), ham yă̆ (HY), ham protein (HP), ham selüloz (HS), ham kül (HK), nişasta analizleri yapılmıştır. Enzimatik yöntemle organik madde sindirilebilirliği (OMS) saptanmıştır. Araştırmada, KM, HY, HP, HS, HK analizi Weende analiz yöntemine göre saptanmıştır (Akyıldız, 1984). OMS düzeyinin saptanması Naumann ve Bassler (1993) tarafından önerilen selülaz yöntemi ile nişasta analizi (AOAC, 1990) metoduna uygun olarak yapılmıştır.

\section{Mikrobiyolojik Analizler}

Çalışmada gerek başlangıç ve gerekse depolama süresince enterobakteri, maya ve küf yoğunluklarının saptanmasına ilişkin analizler yürütülmüştür. Bu amaçla 10 g’lık örnekler peptonlu su aracılığı ile 2 dakikadan az olmamak koşulu ile karıştırılıp mikroorganizmaların mümkün olduğu ölçü de materyalden ayrılması sağlanmıştır. Elde edilen stok materyalden logaritmik seride dilüsyonlar hazırlanarak 1 saati aşmayan zaman zarfında ekim işlemi yapılmıştır. Enterobakteriler için besi ortamı Violet Red Bile Glikoz (VRB) Agar, maya ve küfler için Malt Ekstrakt Agar kullanılmıştır. Örneklere ait enterobakteri sayımları $37{ }^{\circ} \mathrm{C}$ de $18-20$ saatlik, maya ve küfler için $30{ }^{\circ} \mathrm{C}$ sicaklıkta 5 günlük inkübasyon dönemlerini takiben gerçekleştirilmiştir (Seale ve ark., 1990). Örneklerde saptanan enterobakteri, maya ve küf sayıları logaritma koliform üniteye (cfu/g) çevrilmiştir.

\section{Mikroskopik İncelemeler}

Mikroskopik incelemeler, Leica S8APO stereo mikroskop ile ScopeTek photo, (version: 3.0.12.785) programı kullanılarak yapılmıştır. 


\section{İstatistiksel Analizler}

Araştırmada elde edilen verilerin istatistiksel değerlendirilmesinde varyans analizi, gruplar arası farklılığın belirlenmesinde ise Duncan çoklu karşılaştırma testi uygulanmıştır (Soysal, 1998). Bu amaçla Statistica paket programı (1999) kullanılmıştır.

\section{BULGULAR VE TARTIŞMA}

Denemede kullanılan yemlerin depolama öncesi KM, HP, HK, HY, HS, Nişasta, OMS ve mikrobiyolojik özelliklerine ilişkin veriler Çizelge 1'de verilmiştir.

Çizelge 1. Arpanın farklı formlarının başlangıç materyaline ilişkin analiz değerleri

\begin{tabular}{lccc}
\hline & & Yem Formu & \\
\cline { 2 - 4 } Parametreler & Ezme & Öğ̈̈tme & Flake \\
\hline Kuru madde, \% & 89.5 & 89.9 & 90.2 \\
Ham protein, \%KM & 8.2 & 8.1 & 8.7 \\
Ham kül, \%KM & 1.1 & 1.7 & 2.3 \\
Ham yağ, \%KM & 1.6 & 1.8 & 2.1 \\
Ham selüloz, \%KM & 5.7 & 5.6 & 5.6 \\
Nişasta, \%KM & 55.1 & 56.8 & 59.9 \\
Maya, cfu/g TM & 1.76 & 1.64 & 0 \\
Enterobakteri, cfu/g TM & 2.23 & 2.34 & 0 \\
Küf, cfu/g TM & 0.47 & 0.46 & 0 \\
Organik Madde Sindirilebilirliği & 85.0 & 90.2 & 95.9 \\
\hline
\end{tabular}

KM: Kuru madde, TM: Taze materyal, cfu: koloni oluşturan birim

Arpanın farklı formlarının, farklı ortam sıcaklıklarında 90 günlük depolama süresine ilişkin kimyasal analiz değerleri Çizelge 2'de sunulmuştur.

Yemlerin KM, HP, HY, HK, HS ve nişasta değeri üzerinde yemin depolama süresi, depolama sicaklığ1 ve yemin formunun istatistiki olarak önemli olduğu gözlenmektedir $(\mathrm{P}<0.001)$. Yemlerin KM içeriği, depolama süresine bağlı olarak artmıştır. En yüksek KM içeriği 90 . günün sonunda $4{ }^{\circ} \mathrm{C}$ de depolanan flake yem formunda (\%92.19) olarak tespit edilmiştir.

Yemlerin HP içeriği ise depolama sıcaklığı ve depolama süresine bağlı olarak azalmıştır $(\mathrm{P}<0.001)$. HP içeriği üzerinde yemin formu etkili olmuş, en düşük HP içeriği yemlerin ögütme formunda tespit edilirken, flake yem formunda HP miktarı daha yüksek tespit edilmiştir $(\mathrm{P}<0.001)$. Bu konuda yapılan benzer bir çalışmada ise HP içeriğinde herhangi bir değişiklik tespit edilmemiştir (Kruma ve ark., 2018).

Yemlerin HY içeriği depolama süresine bağlı olarak azalmıştır $(\mathrm{P}<0.001)$. HY içeriği üzerinde yemin depolama sıcaklığı $(\mathrm{P}<0.05)$ ve yemin formu etkili olmuş $(\mathrm{P}<0.001)$, en yüksek $\mathrm{HY}$ içeriği ezme formunda $32{ }^{\circ} \mathrm{C}$ depolanan yemlerde tespit edilmiştir $(\mathrm{P}<0.001)$. Yapılan bir çalışmada araştırmacılar 6 aylık depolamadan sonra kahvaltılık tahılların besin değerinde ki değişimlerini incelemişlerdir. Araştırma sonucunda depolama sırasında, yağ içeriğinde önemli bir azalma gözlenmiştir. Bunun nedeninin uygulamalar ve ambalaj malzemesi olabileceği ifade edilmiştir. Çalışmada yağ içeriğinin azalmasının ise büyük olasılıkla oksidasyonun sonucu olduğu saptanmıştır (Kruma ve ark., 2018).

Yemlerin HK içeriği üzerinde depolama süresi ve formu etkili olmuştur $(\mathrm{P}<0.001)$, ancak yemin depolama sıcaklığının herhangi bir etkisi tespit edilmemiştir.

Yemlerin depolama süresi, depolama sıcaklığı ve yem formu HS içeriğini farklı şekilde etkilemiştir $(\mathrm{P}<0.001)$. En yüksek HS içeriği 90 . günün sonunda $32^{\circ} \mathrm{C}$ 'de depolanan ezme yem formunda (\%5.91 KM) olarak tespit edilmiştir. 
Yemlerin nişasta içerikleri \%54.83 - 58.12 oranında değişmiştir. Nişasta içeriği, öğütme formunda ki yemlerde, depolama sıcaklığı ve depolama süresine bağlı olarak düşmüştür $(\mathrm{P}<0.001)$. En yüksek nişasta içeriği 90. günün sonunda $22{ }^{\circ} \mathrm{C}$ 'de depolanan flake yem formunda (\%58.12) olarak tespit edilmiştir. Muruza ve Çelik (2020) yürüttükleri bir çalışmada bazı arpa çeşitlerinin nişasta içerikleri \%50.37-53.17 arasında tespit edilmiştir. Araştırma sonuçları değerlendirildiğinde yemlerin nişasta içeriklerinin uygulanan işleme göre arttığını söyleyebiliriz.

Çizelge 2. Arpanın farklı formlarının kimyasal kompozisyonuna ilişkin analiz değerleri (\%KM)

\begin{tabular}{|c|c|c|c|c|c|c|c|c|}
\hline Gün & Sicaklık & Form & KM \% & HP & HY & HK & HS & Nişasta \\
\hline \multirow{9}{*}{30} & \multirow{3}{*}{$4^{\circ} \mathrm{C}$} & Ezme & $90.88 \mathrm{kl}$ & $8.12 \mathrm{ij}$ & $1.84 \mathrm{fg}$ & $1.51 \mathrm{de}$ & $5.43 \mathrm{de}$ & $57.65 \mathrm{hi}$ \\
\hline & & Öğütme & $90.89 \mathrm{jkl}$ & $8.11 \mathrm{ij}$ & $1.82 \mathrm{gh}$ & $1.51 \mathrm{de}$ & $5.22 \mathrm{ghi}$ & 58.06 \\
\hline & & Flake & $91.37 \mathrm{e}$ & $8.06 \mathrm{ij}$ & $1.83 \mathrm{fg}$ & 1.62 & $5.64 \mathrm{~b}$ & $56.76 \mathrm{n}$ \\
\hline & \multirow{3}{*}{$22^{\circ} \mathbf{C}$} & Ezme & $90.37 \mathrm{n}$ & $7.48 \mathrm{~m}$ & $1.74 \mathrm{~h}$ & 1.63 & $5.34 \mathrm{def}$ & $57.56 \mathrm{ij}$ \\
\hline & & Öğütme & 90.28 o & $7.42 \mathrm{n}$ & $1.63 \mathrm{I}$ & $1.54 \mathrm{de}$ & $5.44 \mathrm{~d}$ & $59.24 \mathrm{a}$ \\
\hline & & Flake & $91.16 \mathrm{~g}$ & 7.521 & $1.62 \mathrm{I}$ & $1.42 \mathrm{de}$ & $5.33 \mathrm{efg}$ & $58.15 \mathrm{~d}$ \\
\hline & \multirow{3}{*}{$32^{\circ} \mathbf{C}$} & Ezme & $91.17 \mathrm{~g}$ & $8.81 \mathrm{c}$ & $2.13 \mathrm{ab}$ & $2.12 \mathrm{a}$ & $5.34 \mathrm{def}$ & $56.54 \mathrm{o}$ \\
\hline & & Öğütme & $91.08 \mathrm{gh}$ & $8.52 \mathrm{f}$ & $2.22 \mathrm{a}$ & $2.03 \mathrm{a}$ & 5.14 aijk & $57.44 \mathrm{kl}$ \\
\hline & & Flake & $91.37 \mathrm{e}$ & $9.31 \mathrm{a}$ & $2.04 \mathrm{~cd}$ & $2.02 \mathrm{a}$ & $5.33 \mathrm{efg}$ & $56.54 \mathrm{o}$ \\
\hline \multirow{9}{*}{60} & \multirow{3}{*}{$4^{\circ} \mathbf{C}$} & Ezme & $91.08 \mathrm{gh}$ & $8.03 \mathrm{j}$ & $1.82 \mathrm{gh}$ & $1.51 \mathrm{de}$ & $5.34 \mathrm{def}$ & 57.73 \\
\hline & & Öğütme & $91.37 \mathrm{e}$ & $8.07 \mathrm{ij}$ & $1.92 \mathrm{ef}$ & $1.52 \mathrm{de}$ & $5.14 \mathrm{ijk}$ & $58.42 \mathrm{c}$ \\
\hline & & Flake & $91.96 \mathrm{~b}$ & $8.13 \mathrm{i}$ & $1.82 \mathrm{gh}$ & 1.62 & $5.34 \mathrm{def}$ & 57.341 \\
\hline & \multirow{3}{*}{$22^{\circ} \mathbf{C}$} & Ezme & 90.861 & $8.03 \mathrm{j}$ & $1.83 \mathrm{fg}$ & $1.43 \mathrm{de}$ & $5.34 \mathrm{def}$ & $57.53 \mathrm{ij}$ \\
\hline & & Öğütme & $91.06 \mathrm{hi}$ & $7.81 \mathrm{k}$ & $1.91 \mathrm{fg}$ & $1.82 \mathrm{~b}$ & $5.63 \mathrm{bc}$ & $56.94 \mathrm{~m}$ \\
\hline & & Flake & $91.48 \mathrm{~d}$ & $8.11 \mathrm{ij}$ & $1.84 \mathrm{fg}$ & 1.62 & $5.24 \mathrm{fgh}$ & 57.54 \\
\hline & \multirow{3}{*}{$32^{\circ} \mathbf{C}$} & Ezme & $90.68 \mathrm{~m}$ & $8.32 \mathrm{~g}$ & $1.93 \mathrm{ef}$ & $2.02 \mathrm{a}$ & 5.22 ghij & 57.62 \\
\hline & & Öğütme & $91.28 \mathrm{f}$ & $8.71 \mathrm{~d}$ & $2.03 \mathrm{cde}$ & $1.76 \mathrm{bc}$ & 4.941 & $58.64 \mathrm{~b}$ \\
\hline & & Flake & $91.88 \mathrm{~b}$ & $9.03 \mathrm{~b}$ & $2.12 \mathrm{bc}$ & $2.04 \mathrm{a}$ & $5.33 \mathrm{efg}$ & 56.62 o \\
\hline \multirow{9}{*}{90} & \multirow{3}{*}{$4^{\circ} \mathbf{C}$} & Ezme & $91.16 \mathrm{~g}$ & $8.04 \mathrm{ij}$ & $1.83 \mathrm{fg}$ & 1.63 & $5.32 \mathrm{fg}$ & $57.81 \mathrm{~g}$ \\
\hline & & Öğütme & $91.58 \mathrm{c}$ & $7.81 \mathrm{k}$ & $1.84 \mathrm{fg}$ & $1.51 \mathrm{de}$ & $5.31 \mathrm{fg}$ & $58.02 \mathrm{ef}$ \\
\hline & & Flake & $92.19 \mathrm{a}$ & $8.13 \mathrm{i}$ & $1.92 \mathrm{efg}$ & $1.42 \mathrm{e}$ & $5.11 \mathrm{k}$ & $57.94 \mathrm{f}$ \\
\hline & \multirow{3}{*}{$22^{\circ} \mathrm{C}$} & Ezme & $90.97 \mathrm{ij}$ & $8.04 \mathrm{ij}$ & $2.05 \mathrm{bc}$ & 1.72 & $5.53 \mathrm{c}$ & $57.64 \mathrm{hi}$ \\
\hline & & Öğütme & $90.96 \mathrm{jk}$ & $7.82 \mathrm{k}$ & $1.94 \mathrm{de}$ & $1.81 \mathrm{bc}$ & $5.14 \mathrm{ijk}$ & 58.05 \\
\hline & & Flake & $91.38 \mathrm{e}$ & $8.22 \mathrm{~h}$ & $1.84 \mathrm{fg}$ & 1.62 & $5.32 \mathrm{fg}$ & 58.12 \\
\hline & \multirow{3}{*}{$32^{\circ} \mathrm{C}$} & Ezme & $90.66 \mathrm{~m}$ & $8.82 \mathrm{e}$ & $2.14 \mathrm{ab}$ & $2.21 \mathrm{a}$ & $5.91 \mathrm{a}$ & $54.83 \mathrm{r}$ \\
\hline & & Öğütme & $90.96 \mathrm{jk}$ & $8.62 \mathrm{c}$ & $2.04 \mathrm{~cd}$ & $2.03 \mathrm{a}$ & $5.63 \mathrm{bc}$ & $56.43 \mathrm{p}$ \\
\hline & & Flake & $91.88 \mathrm{~b}$ & $8.82 \mathrm{c}$ & $2.02 \mathrm{cde}$ & $2.02 \mathrm{a}$ & $5.12 \mathrm{jk}$ & $57.52 \mathrm{jk}$ \\
\hline \multicolumn{2}{|c|}{ SEM } & & 0.062 & 0.071 & 0.021 & 0.033 & 0.028 & 0.115 \\
\hline \multicolumn{9}{|c|}{$P$} \\
\hline \multicolumn{2}{|c|}{ Süre } & & $<0.001$ & $<0.00$ & $<0.00$ & $<0.05$ & $<0.001$ & $<0.0$ \\
\hline \multicolumn{2}{|c|}{ Sicaklık } & & $<0.001$ & $<0.00$ & $<0.05$ & 0.309 & $<0.001$ & $<0.0$ \\
\hline \multicolumn{2}{|c|}{ Form } & & $<0.001$ & $<0.00$ & $<0.00$ & $<0.001$ & $<0.01$ & $<0.0$ \\
\hline \multicolumn{2}{|c|}{ Süre x Sicaklık } & & $<0.001$ & $<0.00$ & $<0.00$ & $<0.01$ & $<0.001$ & $<0.0$ \\
\hline \multicolumn{2}{|c|}{ Süre x Form } & & $<0.001$ & $<0.00$ & $<0.00$ & $<0.01$ & $<0.001$ & $<0.0$ \\
\hline \multicolumn{2}{|c|}{ Sicaklık x Form } & & $<0.001$ & $<0.00$ & $<0.01$ & $<0.002$ & $<0.001$ & $<0.0$ \\
\hline \multicolumn{2}{|c|}{ Süre x Sicaklık x Form } & & $<0.001$ & $<0.00$ & $<0.00$ & $<0.05$ & $<0.001$ & $<0.0$ \\
\hline
\end{tabular}

Arpanın farklı formlarının farklı sıcaklık ve depolama süresine ilişkin mikrobiyolojik analiz değerleri Çizelge 3'de sunulmuştur. Depolama süresine bağlı olarak yemlerin maya, küf ve enterobakteri 
içeriği artmıştır. $32{ }^{\circ} \mathrm{C}$ 'de depolanan yemlerin hiçbir formunda maya küf ve enterobakteri gelişimi olmamıştır $(\mathrm{P}<0.001)$. Mayalar, laktik asidi metabolize ederek depolama sisteminin koruyucu özelliklerini azaltabilirken, aynı zamanda yemlerin tatların bozulmasına da neden olur ancak mikotoksin üretmezler (Kurtzman ve Fell, 1998, Brooks ve ark., 2001, Beal ve ark., 2005).

Çizelge 3. Arpanın farklı formlarının mikrobiyolojik kompozisyonuna ilişkin analiz değerleri (cfu/g TM)

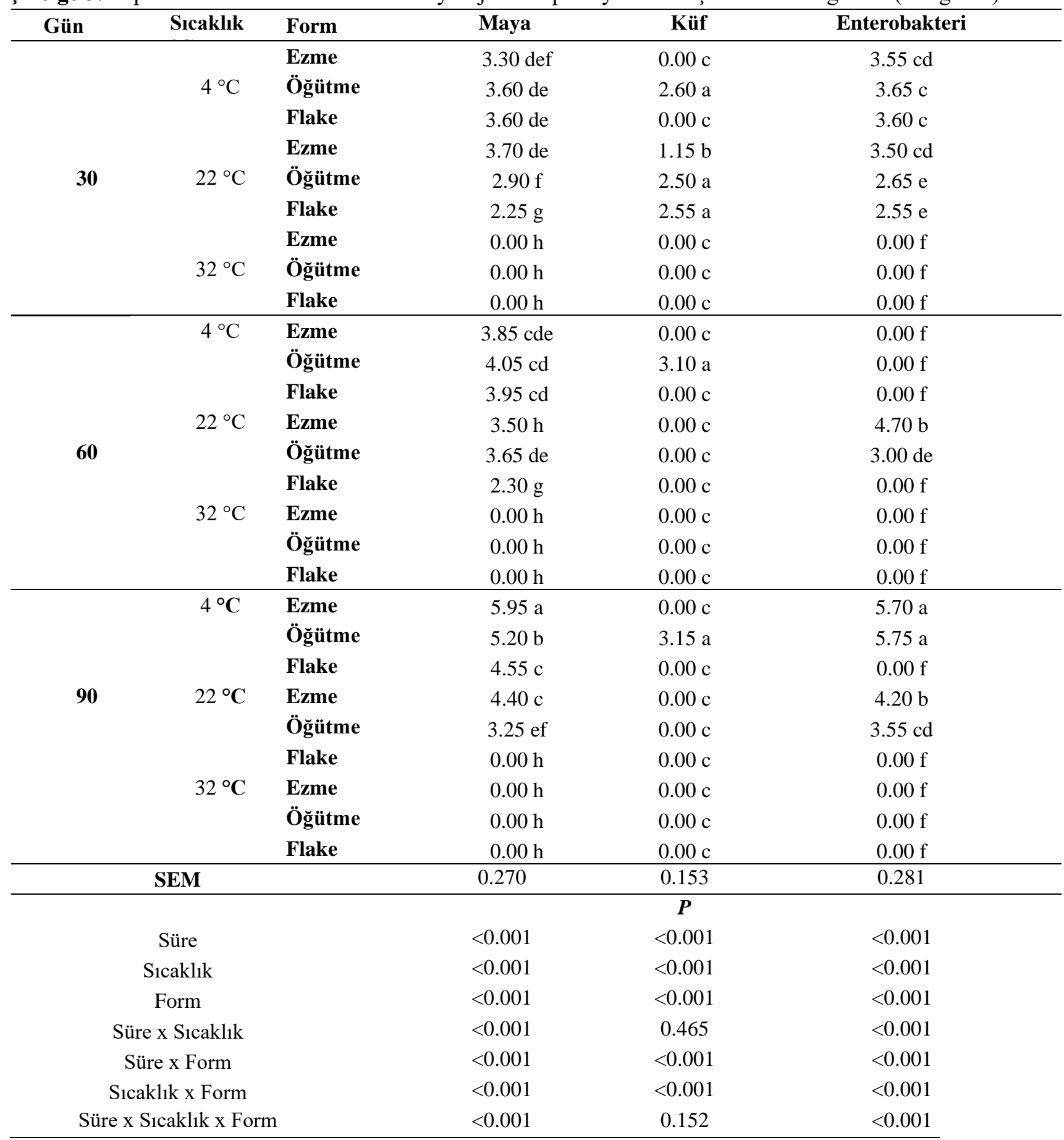

cfu: koloni oluşturan birim.; : Aynı sütunda farklı harfler arasındaki farklılıklar önemlidir ( $<<0.01)$.

Çalışmada yemin formu, mikrobiyal kompozisyonu üzerinde belirgin şekilde etkili olmuştur. Öğütme ve ezme formundaki yemlerin mikroorganizma yükleri daha yüksek tespit edilmiştir. Yemlerde ki mikrobiyal bozulmalardaki en önemli etmenler nem oranı, depolama sıcaklığ ve depolama süresidir. Yapılan çalışmalarda \%18 nem içeriğine sahip tahıl tanelerinin $4.4{ }^{\circ} \mathrm{C}$ de 200 gün, $\% 12$ nem içeriğinde $21{ }^{\circ} \mathrm{C}$ de 60 hafta ve $\% 13$ nem içeriğinde $26.66{ }^{\circ} \mathrm{C}$ de 16 hafta olarak belirtilmiştir (Hellevang, 2014). 
Çizelge 4. Arpanın farklı formlarının OMS değerleri

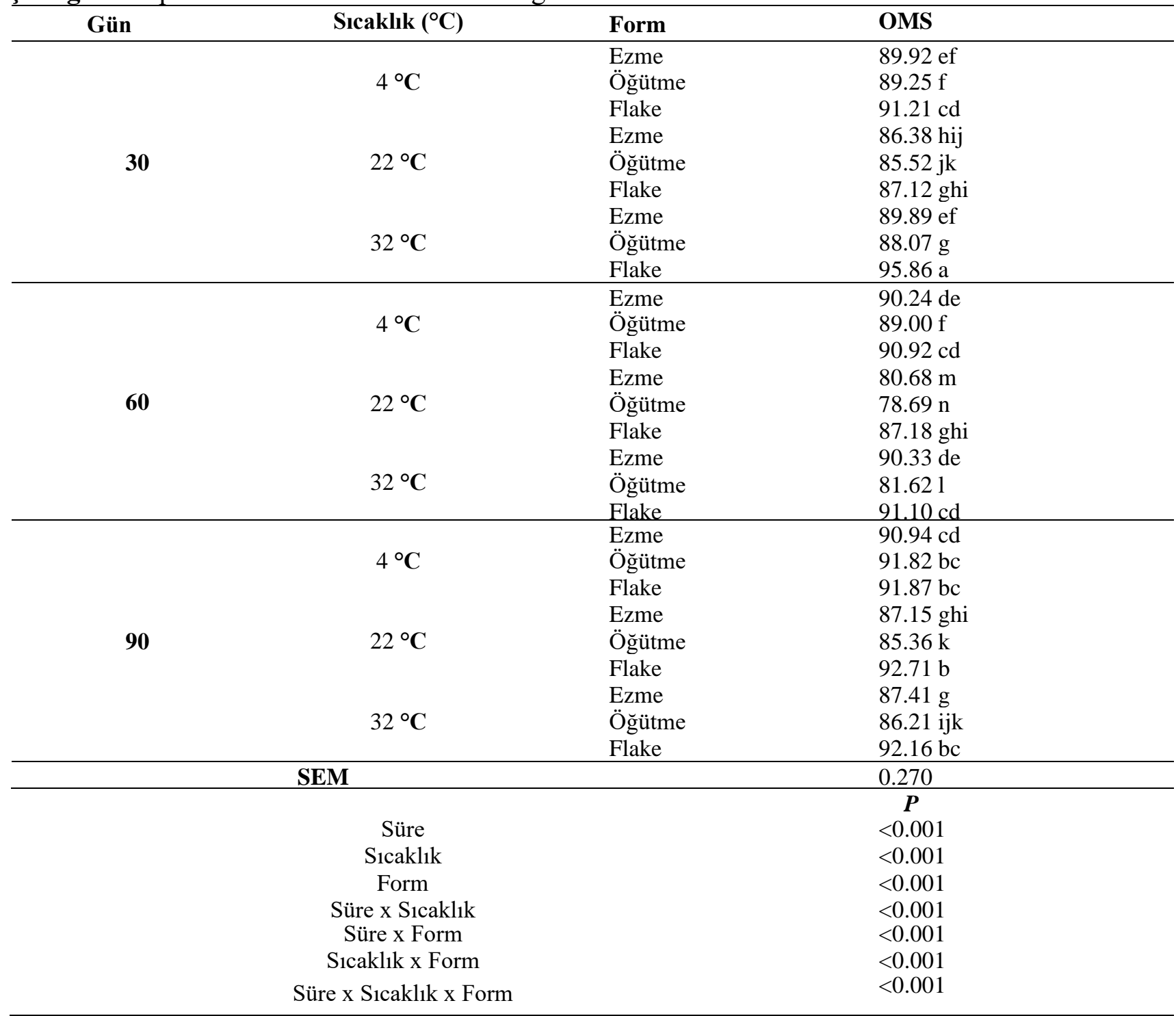

OMS: Organik madde sindirilebilirliği.;* : Aynı sütunda farklı harfler arasındaki farklılıklar önemlidir (P<0.01).

Yemlerin OMS düzeyleri üzerinde depolama süresi, sıcaklığı ve formunun istatistik olarak önemli olduğu gözlenmektedir $(\mathrm{P}<0.001)$.

Yemlerin OMS düzeylerinin başlangıç materyaline oranla arttığı tespit edilmiştir. Tahılların sindirilme dereceleri uygulanan işlem tekniği ve tahılın çeşidine göre farklılık gösterebilmektedir. Yem işleme tekniklerinin sığırlarda arpanın sindirilebilirliğini arttırdığı belirtilmektedir (Campling, 1991; Owens ve ark., 1997). Tüm dane arpa ile beslenen besi sığırlarında arpanın organik madde sindirilebilirliği ortalama \% 52.5 iken, kuru ezme işleminden geçirilmiş arpa ile besleme de bu oran \% 85.2 olarak tespit edilmiştir (Toland, 1976). Lardy (2018) yaptı̆̆ 1 bir araştırmada mısırın rumende sindirilebilirliğinin kırma ve ezme gibi yem işleme yöntemleri ile \% 5-10 oranında arttırılabileceği bildirilmiştir. Süt ineklerinde öğütülmüş mısır ile beslemenin kuru madde tüketimini azalttı̆̆ı, buna karşın yemden yararlanma oranını iyileştirdiği kaydedilmiştir (Yu ve ark., 1998). Zhang ve ark. (2010), süt emen buzağılarda yürüttükleri çalışmada flake mısır ve soya ağırlıklı buzağı başlatma yemi ile beslenen hayvanlarda yemden yararlanmanın iyileştiği, sütten kesimden sonra ishale yakalanma oranının azaldığını tespit etmişlerdir. Bu araştırmada da benzer sonuçlara ulaşılmıştır. Özellikle ezme ve flake formda depolanan arpanın OMS değerleri daha yüksek tespit edilmiştir. 
Arpanın farklı formlarının farklı depolama süresi ve sıcaklıklarında muhafaza edilmesinin etkileri mikroskop ile incelenmiştir (Şekil 1, 2 ve 3).

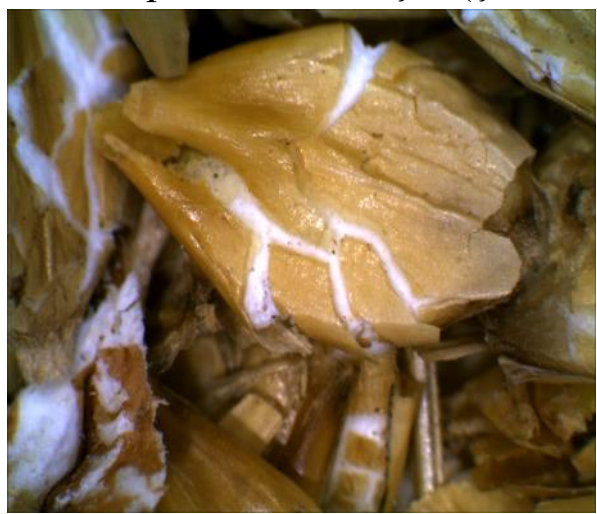

Arpa flake (1x)

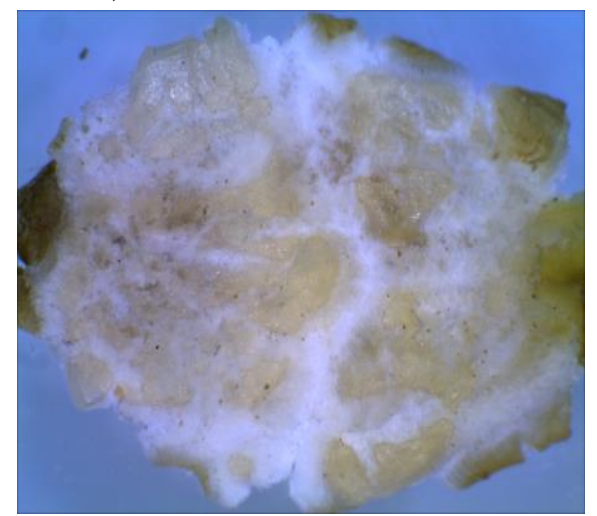

Arpa ezme (1x)

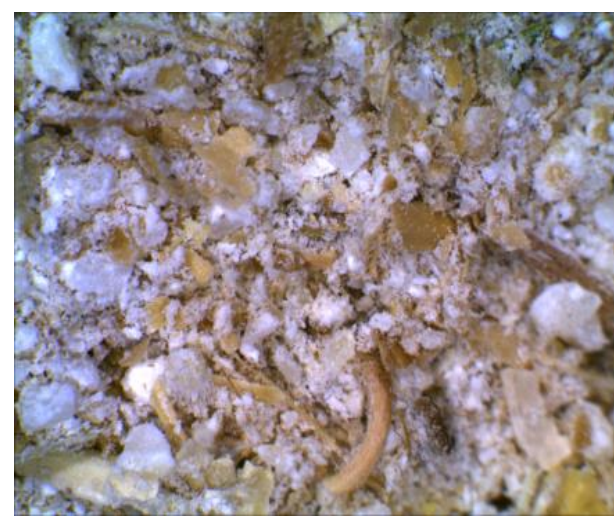

Arpa öğ̈̈tme (1x)

Şekil 1. Arpanın farklı formlarının başlangıç materyallerinin mikroskop altında görünümü (10x).

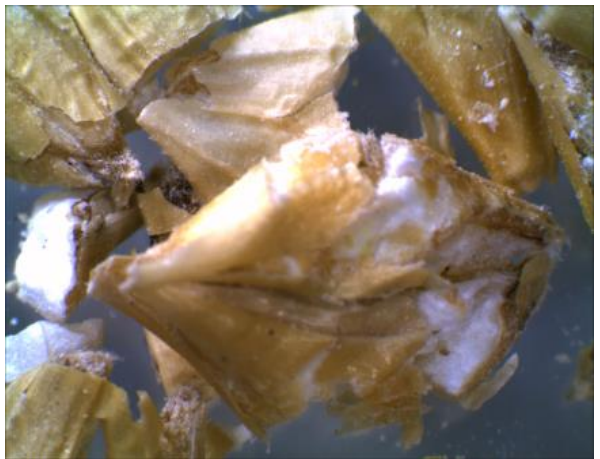

Arpa ezme $4{ }^{\circ} \mathrm{C}(1 \mathrm{x})$

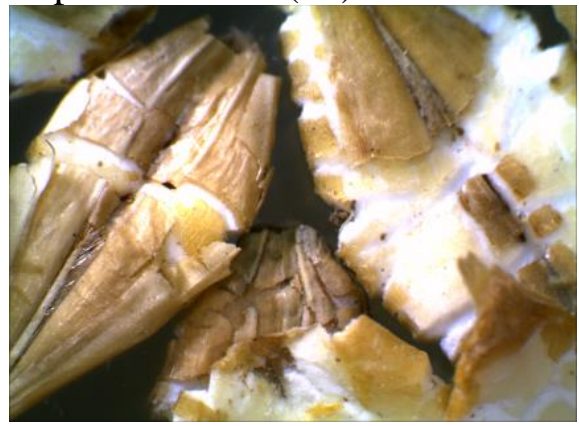

Arpa flake $4{ }^{\circ} \mathrm{C}(1 \mathrm{x})$

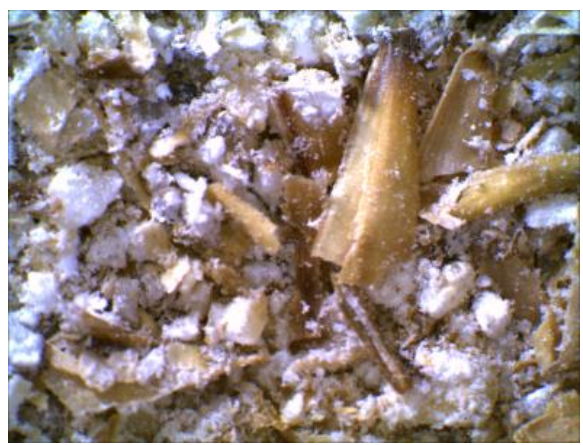

Arpa öğütme $4{ }^{\circ} \mathrm{C}(1 \mathrm{x})$

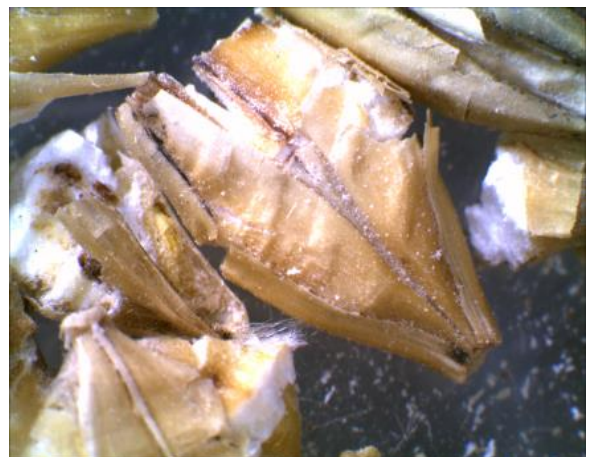

Arpa ezme $22^{\circ} \mathrm{C}(1 \mathrm{x})$

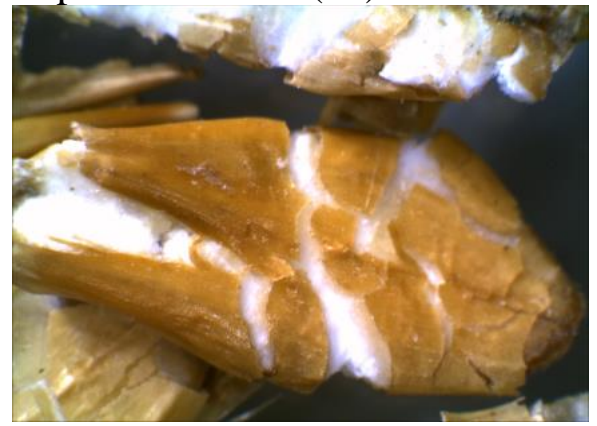

Arpa flake $22^{\circ} \mathrm{C}(1 \mathrm{x})$

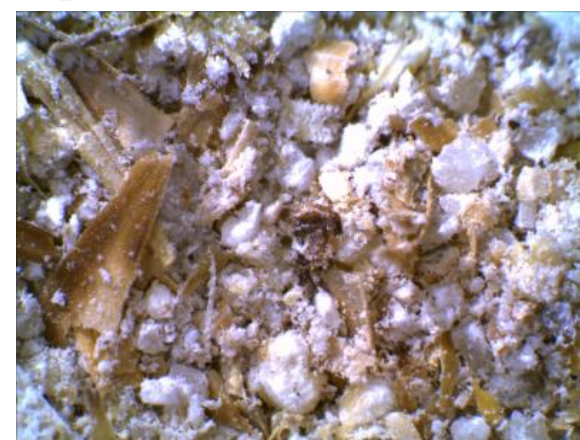

Arpa ögütme $22^{\circ} \mathrm{C}(1 \mathrm{x})$

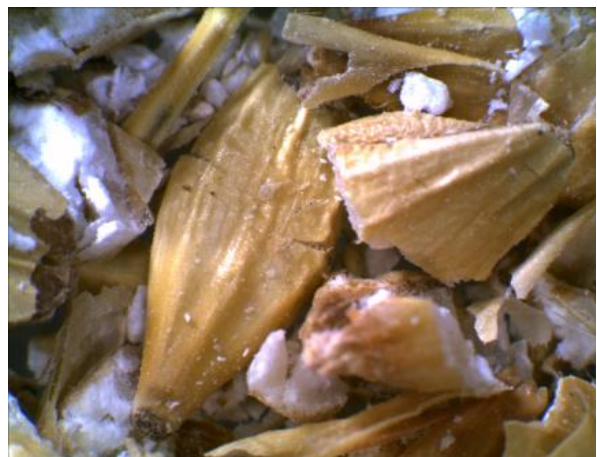

Arpa ezme $32{ }^{\circ} \mathrm{C}(1 \mathrm{x})$

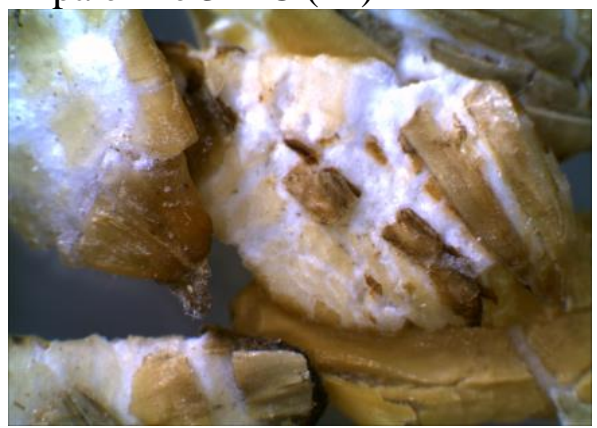

Arpa flake $32{ }^{\circ} \mathrm{C}(1 \mathrm{x})$

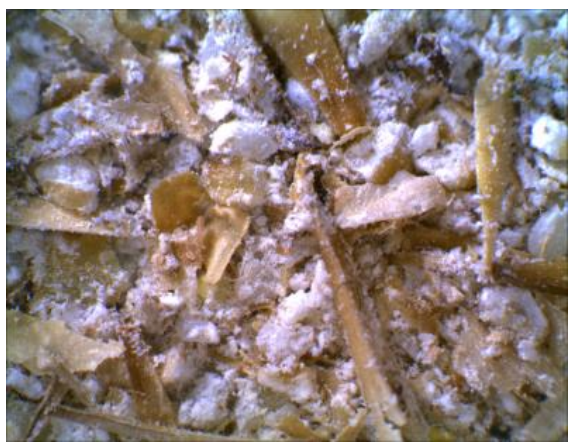

Arpa ögütme $32{ }^{\circ} \mathrm{C}(1 \mathrm{x})$

Şekil 2. Arpanın farklı formlarının 2. ayın sonunda mikroskop altında görünümü (10x). 


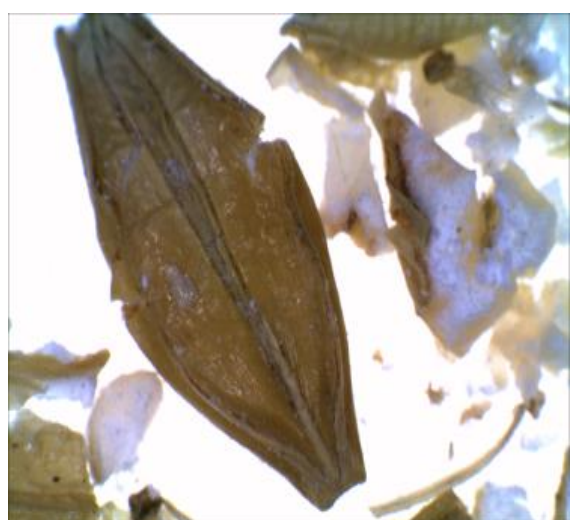

Arpa ezme $4{ }^{\circ} \mathrm{C}(1 \mathrm{x})$

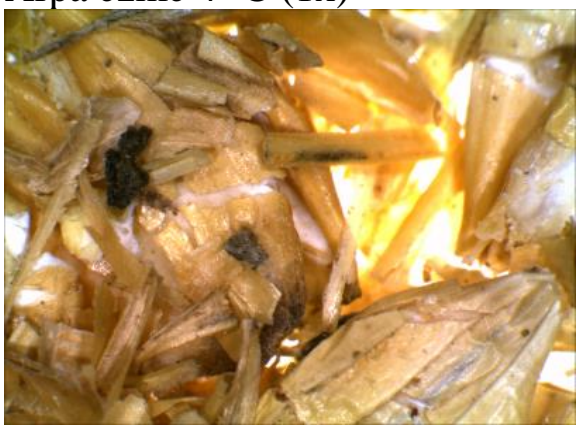

Arpa flake $4{ }^{\circ} \mathrm{C}(1 \mathrm{x})$

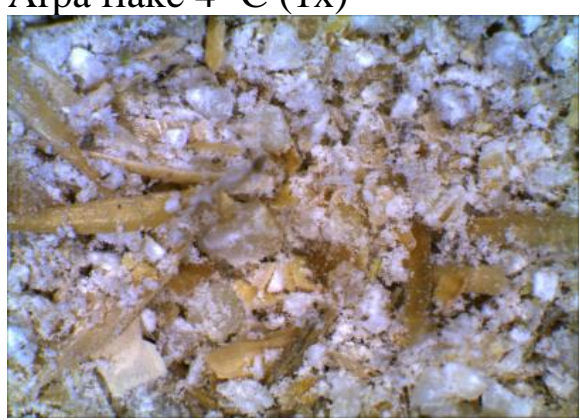

Arpa öğütme $4{ }^{\circ} \mathrm{C}(1 \mathrm{x})$

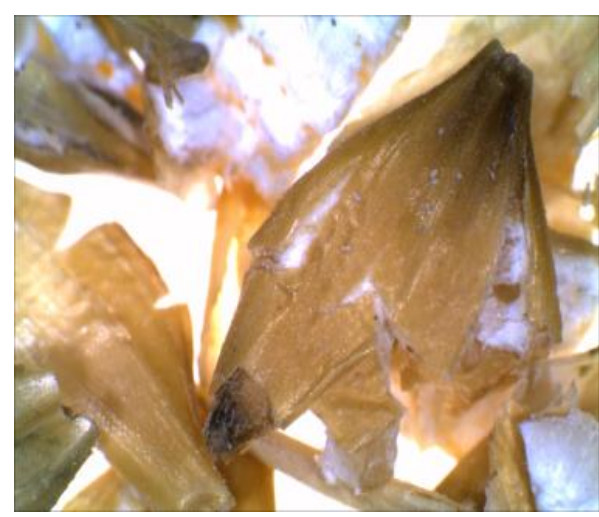

Arpa ezme $22^{\circ} \mathrm{C}(1 \mathrm{x})$

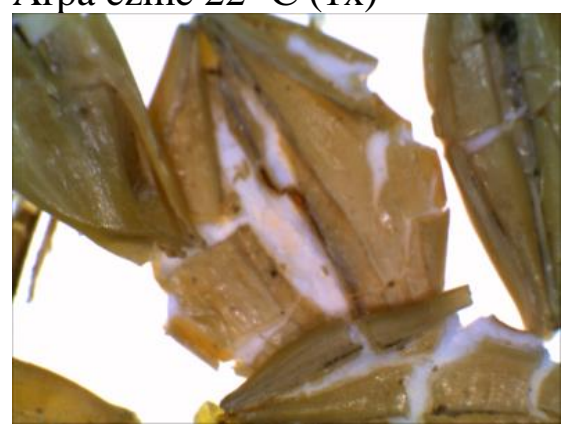

Arpa flake $22{ }^{\circ} \mathrm{C}(1 \mathrm{x})$

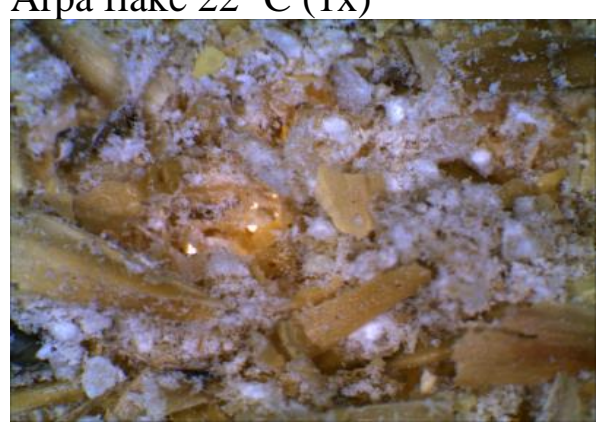

Arpa öğ̈̈tme $22^{\circ} \mathrm{C}(1 \mathrm{x})$

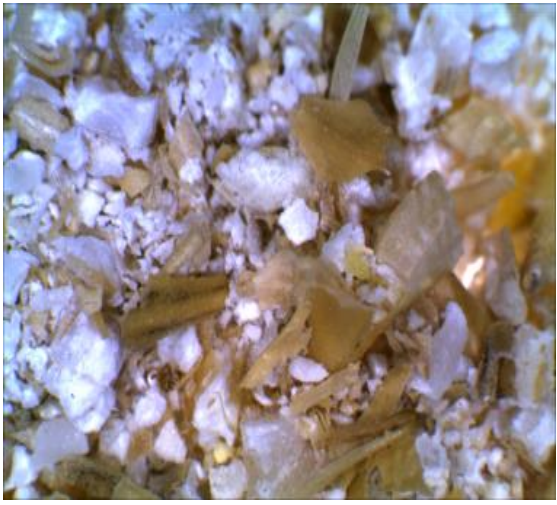

Arpa ezme $32{ }^{\circ} \mathrm{C}(1 \mathrm{x})$
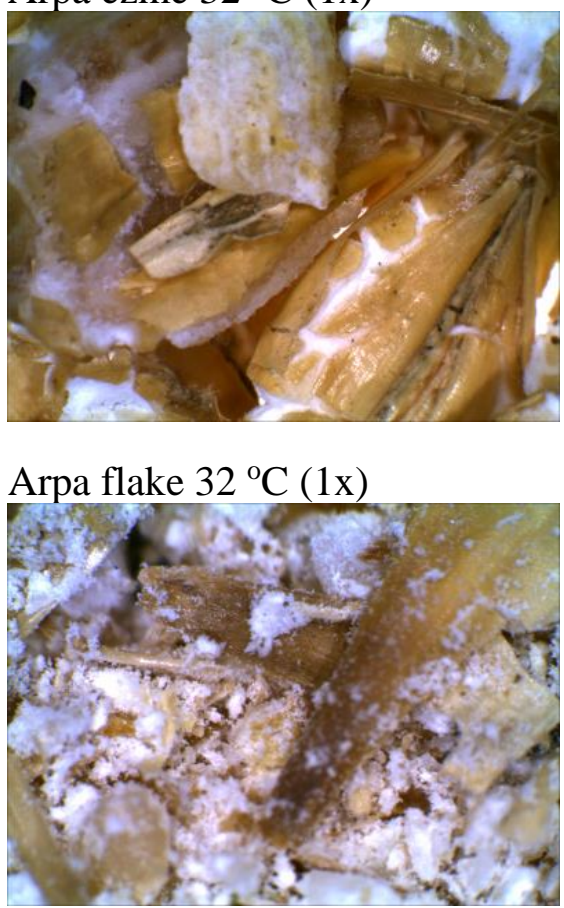

Arpa öğütme $32{ }^{\circ} \mathrm{C}(1 \mathrm{x})$

Şekil 3. Arpanın farklı formlarının 3. ayın sonunda mikroskop altında görünümü (10x).

Mikrobiyolojik analizlerde özellikle yemlerin öğütme ve ezme formlarında tespit edilen küflerin mikroskopta yapılan incelemelerde saptamak mümkün olmamıştır. Laohabanjong ve ark. (2007) tarafından yapılan bir çalışmada farklı depolama şartlarında depolanan balık unlarında kimyasal testlerle mikroskopik değerlendirmeler arasında paralelliklerin saptandığı bildirilmiştir. Farklı depolama süresi ve sıcaklıklarının soya küspesi ve balık ununun bazı özellikleri üzerindeki etkilerinin, mikrobiyolojik ve mikroskopik yöntemlerle belirlenmesine yönelik bir başka çalışmada ise 2 aylık depolama süresince yem hammaddelerinin stereo mikroskop ile incelenmesinde herhangi bir değişiklik gözlenmediği bildirilmektedir (Şamlı ve Onarbay, 2011).

\section{SONUÇ}

Araştırma sonucunda, yemlerin besin madde kompozisyonu üzerinde depolama sıcaklığı ve depolama süresinin etkili olduğunu söyleyebiliriz. Yemlerin besin madde içerikleri ve mikrobiyal kompozisyonu üzerinde yemin formu etkili olmuş en az etkilenme flake formundaki yemlerde tespit edilmiştir. Çalışmada $4{ }^{\circ} \mathrm{C}$ de ve $22^{\circ} \mathrm{C}$ depolanan yemlerin maya ve entorobakteri içerikleri süreye bağ lı olarak artmıştır. Çalışma kapsamında mikroskopla yapılan ölçümlerde küflerin tespiti mümkün 
olmamıştır. Bu bağlamda, stereo mikroskopla yapılan değerlendirmelerin özellikle depolama süresi uzun olan çalışmalarda kullanılabileceğini söyleyebiliriz.

\section{Çıkar Çatışması}

Makale yazarları aralarında herhangi bir çıkar çatışması bulunmamaktadır.

\section{Yazar Katkısı}

Yazarlar makaleye eşit oranda katkı sağlamışlardır.

\section{KAYNAKLAR}

Aky1ldı AR, 1984. Yemler Bilgisi Laboratuvar Kılavuzu. Ankara, 236 s.

AOAC, 1990. Official Methods of Analysis. 15th ed., Association of Official Analytical Chemists, Arlington, Virginia, USA.

Basmacioğlu H, Ergül M, 2002. Silaj Mikrobiyolojisi. Hayvansal Üretim Dergisi 43(1): 12-24.

Beal JD, Niven SJ, Brooks PH, Gill BP, 2005. Variation in short chain fatty acids and ethanol concentration resulting from the natural fermentation of wheat and barley for inclusion in liquid diets for pigs. J. Sci. Food Agric. 85, 433-440.

Brooks PH, Beal, JD, Niven, SJ, 2001. Liquid feeding of pigs: potential for reducing environmental impact and for improving productivity and food safety. Rec. Adv. Anim. Nutr. Aust. 13, 49-63.

Campling RC, 1991. Processing cereal grains for cattle-a review. Livestock Production Science, 28 : 223-234.

Hellevang K, 2014. Tahıl kalitesini korumada tahıl depolama uygulamaları. Değirmenci Dergisi, say1 55: 2014 Temmuz.

Khajarern J, Khajarern S, 2008. Yem Mikroskopisi ve Kalite Kontrol El Kitabı. Üçüncü basım, Çeviri: Çoşkun, B. ve S. Ü. Çizmeci.

Kruma Z, Galoburda R, Tomsone L, Gramatina I, Senhofa S, Straumite E, Klava D, Kince T, Cinkmanis I, Zagorska J, Kunkulberga D, 2018. Changes in the nutritional value of breakfast cereals containing germinated spring grain flakes during storage. Agronomy Research 16 (S2), 14051416.

Kurtzman CP, Fell JW, 1998. The Yeast, A Taxonomic Study. Elsevier Science B.V., Amsterdam, The Netherlands.

Laohabanjong R, Tantikitti C, Benjakul S, 2007. Lipid oxidation of fish meal stored under different storage conditions. Songklanakarin J. Sci. Technol., 29(2): 501-514.

Lardy G, 2018. Feeding corn to beef cattle. https://www.ag.ndsu.edu/publications/livestock/feedi ngcorn-to-beef-cattle. Erişim tarihi: Nisan, 2021.

Mathison GW, 1996. Effects of processing on the utilization of grain by cattle. Animal Feed Science and Technology, 58: 113-125.

Muruza H, Çelik C, 2020. Bazı arpa (Hordeum vulgare L.) çeşitlerinin in vitro gaz üretimi, organik madde sindirilebilirliği, besin maddeleri içerikleri ve enerji değerlerinin karşılaştırılması. Anadolu Tarım Bilim. Derg./Anadolu J Agr Sci, 35 (2020) ISSN: 1308-8750 (Print) 1308-8769 (Online) doi: 10.7161/ omuanajas.673760.

Naumann C, Bassler R, 1993. Die Chemische Untersuchung von Futtermitteln. VDLUFAMethodenbuch, Band III. 3. Erg., Verlag Naumann, Melsungen.

Owens FN, Secrist DS, Hill WJ, Gill DR, 1997. The effect of grain source and grain processing on performance of feedlot cattle: A review. Journal of Animal Science, 75:868-879.

Seale DR, Pahlow G, Spoelstra SF, Lindgren S, Dellaglio F, Lowe JF, 1990. Methods for The Microbiological Analysis of Silage, Proceeding of The Eurobac Conference, 147. Uppsala. 
Soysal Mİ, 1998. Biyometrinin Prensipleri (istatistik I ve II Ders Notlar1). Yayın No:95, Ders Kitab1 No: 64, T.U. Tekirdağ Ziraat Fakültesi, Tekirdağ

Şamlı HE, Onarbay ON, 2011. Farklı Depolama Şartlarının Bazı Protein Kaynaklı Yem Hammaddelerinin Özellikleri Üzerindeki Etkilerinin Belirlenmesi. Tekirdağ Ziraat Fakültesi Dergisi, 8(3): 40-45

Toland PC, 1976. The digestibility of wheat, barley or oat grain fed either whole or rolled at restricted levels with hay to steers. Australian Journal of Experimental Agriculture and Animal Husbandry, 16:71-75

Yu P, Huber JT, Santos FA, Simas JM, Theurer CB, 1998. Effects of ground, steam-flaked, and steamrolled corn grains on performance of lactating cows. Journal of Dairy Science, 81(3):777783.

Zhang YQ, He DCh, Meng QX, 2010. Effect of a mixture of steam-flaked corn and soybeans on health, growth, and selected blood metabolism of Holstein calves. Journal of Dairy Science, 93(5):22712279.

Zinn RA, Ownes FN, Ware RA, 2002. Flaking corn: Processing mechanics, quality standards, and impacts on energy availability and performance of feedlot cattle. Journal of Animal Science, 80:1145-1156. 